\title{
Evaluation of Antioxidant and Cytotoxic Activity of Decalepis hamiltonii on Hep G2 Cancer Cell Lines
}

\author{
G. Swapna ${ }^{1}$, D. Srinivasa Rao ${ }^{2}$, V. Leelavathi ${ }^{3}$ \\ ${ }^{1,2,3}$ Department of Biotechnology, Acharya Nagarjuna University, Guntur -522510
}

\begin{abstract}
Decalepis hamiltonii (Swallow root) belongs to the Asclepediaceae family is a monogenetic climbing shrub endemic to the Deccan peninsula and is used as a culinary spice due to its highly aromatic roots. It is useful as an appetizer, blood purifier, preservative and as a source of bioinsecticide for stored food grains. The present research work aims to identify the enzymatic and non enzymatic antioxidants in animal models, $\mathrm{LDH}$ and cytotoxicity activities using HEP G2 cancer cell lines were studied in vivo models to find the anticancer activity of $D$. hamiltonii methanolic and water extracts. In treated group of animals significant increased levels of enzymatic antioxidants like Superoxide Dismutase, Catalase and Glutathione Peroxidase were observed when compared to toxic group of animals. High concentration of $\mathrm{LDH}$ in $320 \mu \mathrm{g} / \mathrm{ml}$ and $640 \mu \mathrm{g} / \mathrm{ml}$ were identified as compared to other concentrations like $40 \mu \mathrm{g} / \mathrm{ml}$, $80 \mu \mathrm{g} / \mathrm{ml}$ and $160 \mu \mathrm{g} / \mathrm{ml}$. Similarly significant levels of HEP G2 Cell Line viability were predicted at $640 \mu \mathrm{g} / \mathrm{ml}$ of D. hamiltonii extract. These results might conclude the antioxidant and anticancer activity of $D$. hamiltonii extract.
\end{abstract}

Keywords: antioxidants, cytotoxicity, hepatic cancer, cell lines

\section{Introduction}

Plants have been the traditional source for raw materials and finished medicines since the dawn of civilization (Srinivasa Rao et al., 2004). In India, herbal medicines have been the basis of treatment and cure for various diseases, physiological conditions in traditional methods practiced such as Ayurveda, Unani and Siddha. It has been estimated that about 20,000 plant species are known to have worldwide and phytochemical tests have been performed in about 5000 and nearly 1110 species are extensively utilized in Ayurveda (80\%) and Allopathic medicine (33\%) used as drugs (Swapna and Srinivasa Rao, 2013). Indian folk medicine comprises numerous herbal prescriptions for therapeutic purposes which may be as varied as healing wounds, treating inflammation due to infection, skin lesions, leprosy, diarrhoea, scabies, venereal diseases, snake bite and ulcers etc. The realization that many infectious pathogenic microorganisms are fast developing resistance against prevailing drugs has necessitated a search for new sources of antimicrobial compounds. Plants can synthesize a variety of secondary metabolites capable of providing protection against the infectious diseases (Srinivasa Rao et al., 2005).

Decalepis hamiltonii, an endemic and endangered medicinal plant of southern peninsula. It is a liane and is locally called as maredu kommulu or maredu gaddalu (Devi and Latha 2012). Milky latex is present in the entire plant. Roots are harvested during summer months (Vedavathy, 2004). Roots of D.hamiltonii is a natural source of antioxidant and hence reduces the oxidative stress level and beneficial for health (Srivastava et al.,2005).

Majority of world population can't afford to conventional pharmaceutical products due to its high cost and thus have to rely upon the use of traditional and plant derived medicines (Srinivasa Rao et al., 2006). As a result, plant based antihepatocellular carcinoma drugs are being searched all over the world as an alternative to existing drugs. Global estimates indicate that over $3 / 4^{\text {th }}$ of the world population cannot afford the products of the Western pharmaceutical industry due to its high cost and thus have to rely upon the use of traditional, plant-derived medicine (Avni Desai et al.,2008).

Developing countries can ill afford the products of the Western pharmaceutical industry due to their high and rising cost. The World Health Organization, therefore, recommends the inclusion of herbal medicines which are time tested, safe and available at affordable prices in the national health programmes. Moreover, traditional medicines show better culture acceptability, better compatibility and lesser side effects than synthetic drugs. This recognition has made the herbal system once again the center stage of health care program me, not only in India, but the world over (Umadevi et al., 2013).

The most common histologic type of primary liver cancer, hepatocellular carcinoma (HCC), is a malignant tumor arising from hepatocytes, the liver's parenchymal cells. In agreement, in the early twentieth century, Wiliam Osler in the United States also reported that primary liver cancer was rare and are common in Asia and Africa, but are uncommon in Europe and North America. The highest liver cancer incidence rates in the world are reported by registries in Asia and Africa. Approximately $85 \%$ of all liver cancers occur in these areas, with Chinese registries alone, reporting over $50 \%$.

Free radicals have been implicated in many diseases such as cancer, atherosclerosis, diabetes, neurodegenerative disorders and aging. It is believed that higher intake of antioxidant decreases risk of degenerative diseases particularly cardiovascular diseases and cancer. Several studies have shown that plant derived antioxidant related degenerative effects. Antioxidants are being used widely because of their therapeutic effects (Valko et al.,2007) .

HepG2 is a perpetual cell line consisting of human liver carcinoma cells, derived from the liver tissue of a 15-yearold Caucasian male who had a well-differentiated hepatocellular carcinoma. Hepatocellular carcinoma is, worldwide, the fifth most-common cancer. The morphology 


\section{International Journal of Science and Research (IJSR) \\ ISSN (Online): 2319-7064}

Index Copernicus Value (2015): 78.96 | Impact Factor (2015): 6.391

of HepG2 cells is epithelial and they have 55 chromosome pairs. HepG2 cells can be grown successfully at a large scale, and secret many plasma proteins, such as transferring, fibrinogen, plasminogen and albumin. They can be stimulated with human growth hormone. HepG2 are adherent, epithelial-like cells growing as monolayers and in small aggregates. Not tumorigenic in immunocompromised mice.

\section{Materials and Methods}

Media: Eagle's Minimum Essential Medium, 10\% FBS, $0.05 \%$ Trypsin-EDTA.

\section{Plant material}

The Decalepis hamiltonii root used for the investigation was collected from Tirumala Hills, Tirupati, India. The plant roots were authenticated by taxonomist Dr.K.Madhava Chetty, Department of Botany, Sri Venkateswra University, Tirupati, India.

\section{Preparation of extract}

The collected root of D.hamiltonii was dried in shade, crushed to coarse powder and was extracted with different solvents. Sequential extraction of the root powder was done with different solvents with increasing polarity i.e. hexane, chloroform, ethyl acetate, acetone, methanol and water. A total of $50 \mathrm{~g}$ of root powder was extracted in 0.51 of the solvent in glass conical flask on a shaker for $24 \mathrm{~h}$ at room temperature. The extract was filtered with Whatmann paper no. 1 and dried by lyophilization. The methanolic extract was prepared by soxhlet extraction in methanol. A $100 \mathrm{~g}$ of root powder was extracted $\left(\begin{array}{ll}1 & 1\end{array}\right)$ at $50^{\circ} \mathrm{C}$ for $24 \mathrm{~h}$. Methanol was evaporated and the extract weighed $(28 \mathrm{~g})$. The solvents in plant extracts were evaporated under reduced pressure and extracts were stored in desiccators for further investigation of Antioxidant and Cytotoxic activities.

\section{DPPH radical scavenging assay}

The DPPH activity assay is the widely used assay (Goze et al., 2009; Saha et al., 2008; Prasad et al., 2009; Li et al., 2008). DPPH is a radical, which in the presence of antioxidants, is reduced from a stable free radical, 1,1diphenyl-2-picryl hydrazyl (purple) to a diphenyl picryl hydrazine (yellow). Reaction of DPPH with hydroxyl group (R-OH) and R-NO2 produces 2-(4-hydroxylphenyl)-2phenyl-1-picryl hydrazine and 2-(4-nitrophenyl)-2-phenyl-1picryl hydrazine, respectively (Naidoo, 2005). The amount of DPPH reduced is equivalent to the amount of antioxidants present in the study sample, thus the results obtained gives a true reflection of the extract's ability as an antioxidant.

The ability of the extracts to annihilate the DPPH radical (1,1-diphenil-2- picrylhydrazyl) was investigated by the method described by (Blois, 1958). Stock solution of the plant root extracts was prepared to the concentration of 1 $\mathrm{mg} / \mathrm{ml} .100 \mu \mathrm{g}$ of each extracts were added, at an equal volume, to methanolic solution of DPPH $(0.1 \mathrm{mM})$. The reaction mixture is incubated for $30 \mathrm{~min}$ at room temperature; the absorbance was recorded at $517 \mathrm{~nm}$. The experiment was repeated for three times. BHT was used as standard controls. The results are tabulated in Table 1. DPPH scavenging activity of this plant root extract was measured according to the method of Blios (1958). IC50 values of the extracts and concentration of the extracts necessary to decrease the initial concentration of DPPH by $50 \%$ were calculated.

\section{Results and Discussion}

Decalepis is rich source for the various phytochemical constituents such as aldehydes, phenols, inositols, flavanoids, steroids, terpenoids etc. The roots are used for indigestion, appetite and as blood purifier etc.

\section{MTT Cell Proliferation Assay}

Cell proliferation and Viability are major factors to identify the cancer cells. This is a colorimetric assay that measures the reduction of yellow 3-(4,5-dimetyl thiazol-2yl)-2,5 diphenyl tetrazolium bromide [MTT] by mitochondrial succinate dehydrogenase. The MTT enters the cells and passes into the mitochondria where it is reduced to an insoluble, colored (dark purple) formazon product. The cells are then solubilized with isopropanol and the released solubilized formazon is measured spectrophotometrically. Since the reduction of MTT can occur in metabolically active cells the level of activity is a measure of the viability of the cells.

Measurement of cell viability and proliferation forms the basis for numerous in vitro assays of a cell population's response to external factors. The reduction of tetrazolium salts is now widely accepted as a reliable way to examine cell proliferation. The yellow tetrazolium MTT (3-(4, 5dimethylthiazolyl-2)-2, 5-diphenyltetrazolium bromide) is reduced by metabolically active cells, in part by the action of dehydrogenase enzymes, to generate reducing equivalents such as NADH and NADPH. The resulting intracellular purple formazan can be solubilized and quantified by spectrophotometric means. The MTT Cell Proliferation Assay measures the cell proliferation rate and conversely, when metabolic events lead to apoptosis or necrosis, the reduction in cell viability. The number of assay steps has been minimized as much as possible to expedite sample processing. The MTT Reagent yields low background absorbance values in the absence of cells. For each cell type the linear relationship between cell number and signal produced is established, thus allowing an accurate quantification of changes in the rate of cell proliferation. The herbal extract showed a significant effect on growth of the cancer cell lines. 


\section{International Journal of Science and Research (IJSR) \\ ISSN (Online): 2319-7064}

Index Copernicus Value (2015): 78.96 | Impact Factor (2015): 6.391

Table 1: Cell proliferation and viability assay of HEP G2 Cell Line

\begin{tabular}{|l|c|c|c|c|c|}
\hline & 1st Concentration & 2nd Concentration & 3rd Concentration & Average & \% Viability \\
\hline Control & 0.61 & 0.554 & 0.584 & 0.583 & 100.0 \\
\hline $40 \mathrm{ug} / \mathrm{ml}$ & 0.71 & 0.744 & 0.684 & 0.713 & 122.3 \\
\hline $80 \mathrm{ug} / \mathrm{ml}$ & 0.689 & 0.772 & 0.682 & 0.714 & 122.6 \\
\hline $160 \mathrm{ug} / \mathrm{ml}$ & 0.579 & 0.75 & 0.685 & 0.671 & 115.2 \\
\hline $320 \mathrm{ug} / \mathrm{ml}$ & 0.611 & 0.702 & 0.579 & 0.631 & 108.2 \\
\hline $640 \mathrm{ug} / \mathrm{ml}$ & 0.415 & 0.469 & 0.436 & 0.440 & 75.5 \\
\hline
\end{tabular}

From the Table $\mathbf{1}$ it is illustrated that different concentrations $40 \mu \mathrm{g} / \mathrm{ml}, 80 \mu \mathrm{g} / \mathrm{ml}, 160 \mu \mathrm{g} / \mathrm{ml}, 320 \mu \mathrm{g} / \mathrm{ml}$ and
$640 \mu \mathrm{g} / \mathrm{ml}$ of plant extracts and their responses were identified.

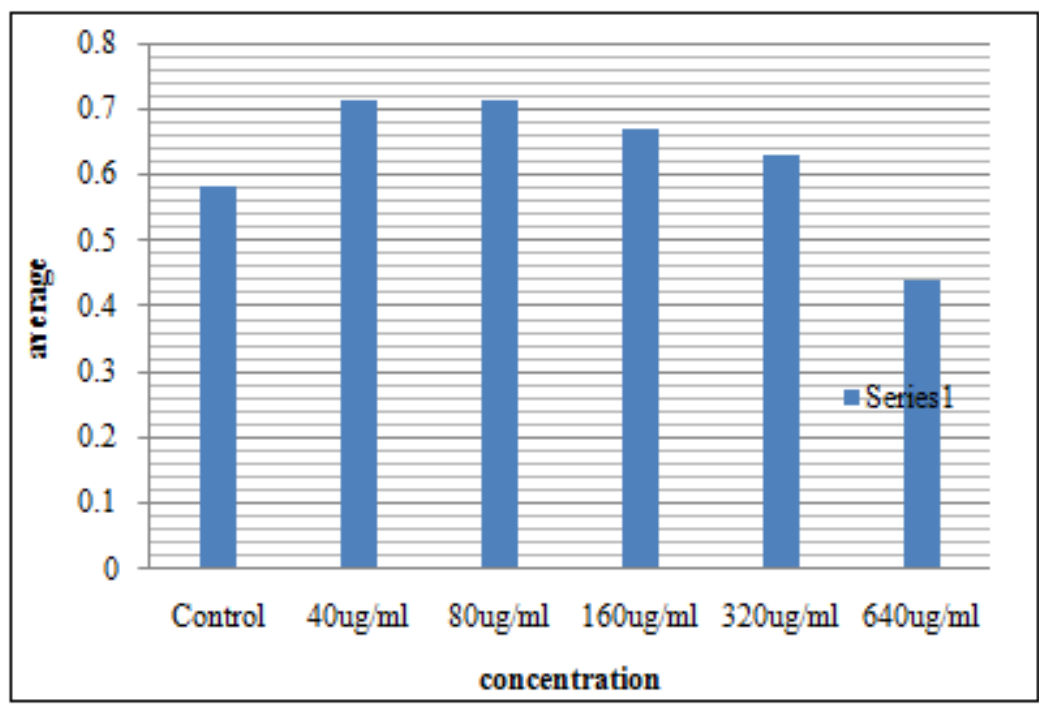

\section{LDH Assay}

Apoptosis and necrosis are two major forms of cell death observed in normal and disease pathologies. Although there are many assays for detection of apoptosis, relatively few assays are available for measuring necrosis. A key signature for necrotic cells is the permeabilization of plasma membrane (Francis Ka-Ming Chan et al., 2014). This event can be quantified in tissue culture settings by measuring the release of the enzyme lactate dehydrogenase (LDH). When combined with other methods, measuring $\mathrm{LDH}$ release is a useful method for detection of necrosis. In this we describe the step-by-step procedure for detection of LDH release from necrotic cells using a microtiter plate based colorimetric absorbance assay. the release of lactate was monitored after 48 hours of treatment in this study. This is because the content of lactate in the medium will affect the cell growth profile. Schneider (1996) reported thatthe toxic action of lactate was probably due to the acidic $\mathrm{pH}$ and osmolarity activity on the cells, particularly at high concentration $(>20 \mathrm{mM})$. In the presence of c-myc, the genes of glycolytic enzymes, namely lactate dehydrogenaseA (LDHA) and GLUT1 would be transactivated to enhance both glucose uptake and lactate production (Shim, 1997).
LDHA was also reported could be upregulated in several tumors and it is essential for c-myc-mediated transformation (Shim, 1997). Actually, lactate was released as the byproduct during cell growth. However, if the concentration of lactate in the medium was too high, it would affect the cell growth. Therefore, the content of lactate is crucial to monitor in order to avoid the side effect of lactate to the growth process of cells. The lactate release profile showed that in fact, the amount of lactate present in the medium did not significantly affect the cell growth (Fig. 3(b)). Hence, the growth profile of the cells was mainly Influenced by the plant extracts, but not because of the content of lactate released into the medium.

Table 2: Lactate Dehydrogenase (U/L)

\begin{tabular}{|l|c|c|c|l|}
\hline & $\begin{array}{c}1^{\text {st }} \\
\text { Concentration }\end{array}$ & $\begin{array}{c}2^{\text {nd }} \\
\text { Concentration }\end{array}$ & $\begin{array}{c}3^{\text {rd }} \\
\text { Concentration }\end{array}$ & Average \\
\hline Control & 28 & 21 & 28 & 26.000 \\
\hline $40 \mathrm{ug} / \mathrm{ml}$ & 28 & 29 & 27 & 28.000 \\
\hline $80 \mathrm{ug} / \mathrm{ml}$ & 25 & 24 & 25 & 24.667 \\
\hline $160 \mathrm{ug} / \mathrm{ml}$ & 24 & 21 & 24 & 23.000 \\
\hline $320 \mathrm{ug} / \mathrm{ml}$ & 23 & 31 & 30 & 28.000 \\
\hline $640 \mathrm{ug} / \mathrm{ml}$ & 44 & 35 & 33 & 37.333 \\
\hline
\end{tabular}


International Journal of Science and Research (IJSR)

ISSN (Online): 2319-7064

Index Copernicus Value (2015): 78.96 | Impact Factor (2015): 6.391

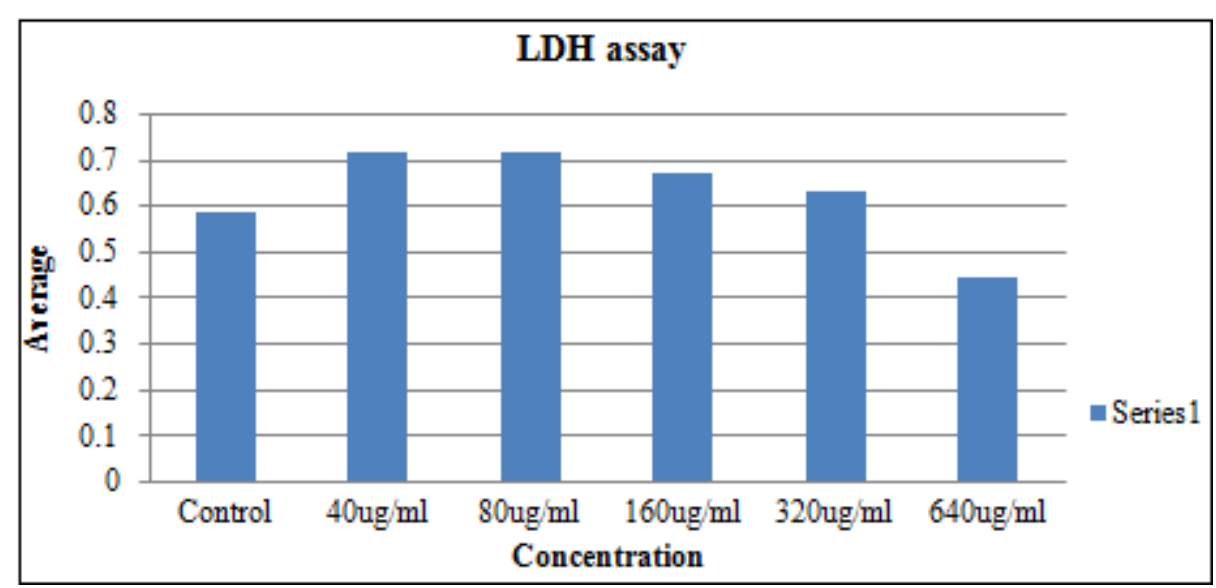

\section{Conclusion}

Interest in the pharmacological effects of bioactive compounds on cancer treatments and prevention has increased dramatically over the past twenty years. It has been shown to possess numerous anti-cancer activities in various cancer cells through different forms of cytotoxic effects without exhibiting considerable damage to normal cells ( Katiyar et al., 2009; Mantena et al., 2006a). Hepatocellular carcinoma (HCC) is the third most common cause of cancer-related deaths worldwide, and about half a million individuals die from this disease annually (El-Serag, 2004; Parkin et al., 2005). Adriamycin (ADM) has been commonly used as a chemotherapeutic drug in the treatment of HCC (Schwartz,2004). However, high concentrations of $\mathrm{ADM}$ tend to cause severe toxicity to normal tissues, including cardiotoxicity (Bristow et al., 1978).Accruing evidences suggest that marine yeast may be a potential chemotherapeutic or a chemopreventive agent based on its ability to induce apoptosis in cancer cells with relatively low toxicity to normal cells. Further studies with in vivo and clinical trials needs to be conducted to establish this herbal drug as a safe agent for cancer therapy (Lau et al., 2001).

\section{References}

[1] Avni G Desai et.,al, Medicinal Plants and cancer prevention, Current Drug Metabolism.2008, 9(7): 581591.

[2] Blois, M.S 1958.Antioxidant determinations by the use of a stable free radical, Nature $29: 1199-1200$.

[3] Francis Ka-Ming Chan et al., The Necroptosis Adaptor RIPK3 Promotes Injury-Induced Cytokine Expression and Tissue Repair, 2014, Immunity,41(4): 567-578.

[4] G.Swapna and D.Srinivasa Rao 2013, Phytochemical Analysis of Endangered Medicinal Plant Decalepis hamiltonii, International Journal of Research in Pharmaceutical and Biomedical Sciences, 4(1), 63-66.

[5] Goze I, Alim A, Tepe AS, Sokmen M, Sevgi K, Tepe B (2009). Screening of the antioxidant activity of essential oil and various extracts of Origanum rotundifolium Boiss. From Turkey. J. Med. Plant. Res. 3(4): 246-254.

[6] Li, H.B.,Wong,C.C., Cheng, K.W., Chen, F. Antioxidant properties in vitro and total phenolic contents in methanol extracts from medicinal plants. Food Sci. Technol. 2008; 41: 385-390.
[7] M. Valko et al., Free radicals and antioxidants in normal physiological functions and human disease, The International Journal of Biochemistry \& Cell Biology 39 (2007) 44-84.

[8] M.Devi and P.Latha 2012, Antibacterial And Phytochemical Studies Of Various Extracts Of Roots of Decalepis hamiltonii Wight And Arn. Int J Pharmacy and Pharmaceutical Sciences, 4(2), 738-740.

[9] Naidoo.V. Screening of four plants commonly used in ethno veterinary medicine for antimicrobial antiprotozoal and antioxidant activity. Dissertation, Faculty of Veterinary Science, University of Pretoria, South Africa, 2004.

[10] Prasad, K.N., Yang, B.,Dong, X., Jiang, G., Zhang, H., Xie, H., and Jiang, Y. (2009). "Flavonoid contents and antioxidant activities from Cinnamomum species," Innovative Food Science and Emerging Technologies10, 627-632.

[11] S.Vedavathy 2004, Decalepis hamiltonii Wight \& Arn. An endangered source of indigenous health drink ,Natural Product Radiancce, 3(1),22-23.

[12] Saha K, Lajis NH, Israf DA, Hamzah AS, Khozirah S, Khamis S, Syahida A (2004). Evaluation of antioxidant and nitric oxide inhibitory activities of selected Malaysian medicinal plants. J. Ethnopharmacol. 92(23): 263-267.

[13] Srinivasa Rao D, Indira A. Jeyraaj and Jeyaraaj R.2004. Evolution of activity of 'pentapala 04' a herbal formulation of the lung lipids against ova albumin and aluminium hydroxide induced lung damage in rats, Ancient Science of life, 23: 9-13.

[14] Srinivasa Rao D, Indira A. Jeyraaj and Jeyraaj, R. 2005. Anti-asthmatic role of 'pentapala 04' A herbal formulation against ova albumin and aluminium hydroxide induced lung damage in rats, Ancient Science of life, 24: 134-142.

[15] SrinivasaRao, D. Indira A. Jayaraaj, Jayaraaj R. and Lakshmi Prabha, M. 2006. A study on antioxidant and anti-inflammatory activity of vasicine against lung damage rats, Indian Journal of allergy, asthma and immunology, 20:1-7.

[16] Srivastava A, Harish R \& Shivanandappa T, Novel antioxidant compounds from the aqueous extract of the roots of Decalepis hamiltonii(Wight and Arn.) and their inhibitory effect on low-density lipoprotein oxidation. J Agric Food Chem, 54 (2006) 790. 


\section{International Journal of Science and Research (IJSR) \\ ISSN (Online): 2319-7064}

Index Copernicus Value (2015): 78.96 | Impact Factor (2015): 6.391

[17] Umadevi et al., (2013), Traditionally Used Anticancer Herbs In India, Journal of Medicinal Plants Studies, 1(3) : 56-74.

[18] Lau CW, Yao XQ, Chen ZY, Ko WH, Huang Y, (2001),Cardiovascular actions of berberine. Cardiovascular Drug Reviews; 3:234 -244.

[19] Bristow MR, Thompson PD, Martin RP, Mason JW, Billingham ME, Harrison DC(1978). Early anthracycline cardiotoxicity. Am J Med : 65:823.832.

[20] Parkin DM(1), Bray F, Ferlay J, Pisani P (2005), Global cancer statistics 2004CA Cancer J Clin.55(2):74-108.

[21]El-Serag HB, Tran T, Everhart JE (2004), Diabetes increases the risk of chronic liver disease and hepatocellular carcinoma. X Gastroenterology,126: 2:460-468.

[22] Katiyar, RS; Singhvi, NR; Kushwaha, RV; Ramji Lal; Suryanarayana, N.. VA-mycorrhizal association in arjuna and jamun trees in forest of Bhandara region, Maharashtra, India. International Journal of Agricultural Sciences. 2009:4(1):229.

[23] Mantena SK, Sharma SD, Katiyar SK. Berberine, a natural product induces G1-phase cell cycle arrest and caspase-3-dependent apoptosis in human prostate carcinoma cells. Molecular Cancer Therapeutics . 2006; 5: 296-308. 